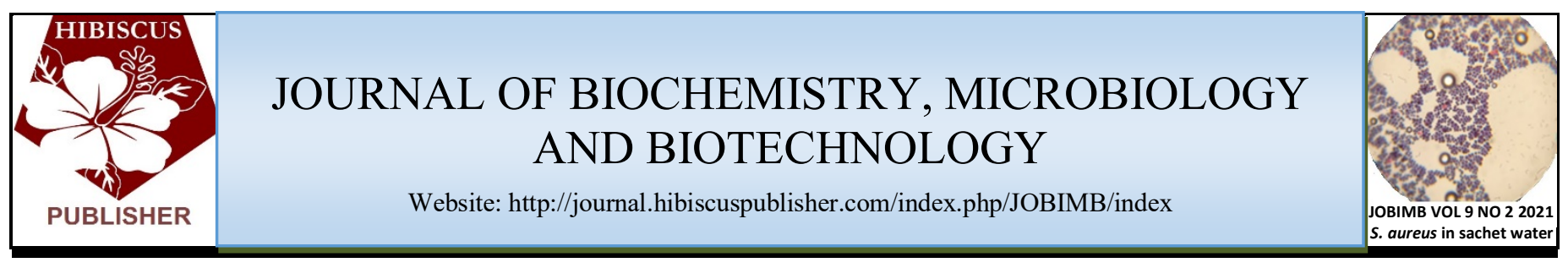

\title{
Phytoremediation of Heavy Metals in Contaminated Soils: A Review
}

\author{
Ibrahim Alkali Allamin ${ }^{1 *}$ \\ ${ }^{1}$ Department of Microbiology, Faculty of Sciences, University of Maiduguri, P.M.B. 1069, \\ Maiduguri, Borno State, Nigeria. \\ *Corresponding author: \\ Dr. Ibrahim Alkali Allamin, \\ Department of Microbiology, \\ Faculty of Sciences, \\ University of Maiduguri, P.M.B. 1069, \\ Maiduguri, Borno State, \\ Nigeria. \\ Email: ibnallamin@gmail.com / ibnallaminmcb@unimaid.edu.ng
}

\section{HISTORY \\ Received: $15^{\text {th }}$ July 2021 \\ Received in revised form: $28^{\text {th }}$ Nov 2021 \\ Accepted: $15^{\text {th }}$ Dec 2021}

\section{KEYWORDS \\ Bioremediation Heavy metals \\ Phytoremediation \\ Phytoremediation \\ Contaminated soils}

\begin{abstract}
Heavy metals represent a major threat to public health and the environment if they are intentionally or unintentionally introduced into the soil. They are elements that cannot be degraded and can be teratogenic, mutagenic, and endocrine-disrupting. Carcinogens and toxins in humans can be caused by heavy metals, which are difficult to regulate. Phytoremediation has been recommended as an alternative to classic physicochemical remediation methods since it is more efficient for combating heavy metals pollution in soil or water bodies and ecologically friendly. Biomass produced as a result of phytoremediation can be utilised for cogeneration of energy and/or the creation of biofuels, all of which contribute to health, the environment, and cost-effectiveness. In order to improve the usage of phytoremediation in the coming years, a deeper understanding of the technique's potential is necessary. Additionally, this study provides information on the use of herbaceous and woody plants for phytoremediation in soils affected by heavy metals.
\end{abstract}

\section{INTRODUCTION}

Scientists all across the globe are still concerned about the presence of dangerous materials in soil and water. Contamination of water and soil has been caused by a variety of human activities, such as garbage disposal, agriculture, and human industry [1]. Furthermore, animate chemicals and dense metals have contaminated the environment, putting both wildlife and humans in danger for serious health concerns [2]. Despite the fact that typical soil treatment procedures are excessively expensive, the participation of a soil depot in the chosen field does not result in an immediate cure, but rather only postpone the problem until a later time period. As a result, the analysis and development of novel solutions to the problem of hazardous contaminants are required [1].

Increased usage of synthetic chemical compounds, whether excessively or inappropriately, has resulted in major environmental issues as well as an increase in a range of negative health impacts (toxicity and carcinogenicity). In addition to having a significant impact on the environmental matrix (air, water, soil, and biota), the emission of solid, liquid, and gaseous waste, which includes contaminants such as heavy metals or petroleum or organic solvents, has had a massive effect on the biodiversity [3]. Therefore, soil contamination can be produced by pollutants that have been injected directly into the soil or by contaminants that have been transported from other matrices into the soil [4]. It is a big public health concern that environmental pollution exists. A multitude of mechanisms of exposure to environmental pollutants is possible for humans, including particulate matter intake, direct contact with the contaminant, ingestion, and ingestion through the food chain [5]. Through the reclamation and reuse of polluted sites, it is feasible to protect both human health and the environment in an environmentally friendly manner.

Furthermore, environmentally friendly remediation operations reduce the quantity of trash produced by physicochemical procedures such as soil incineration or excavation, as well as the amount of rubbish transferred to a landfill, by a significant margin. A number of disadvantages of these treatments are also present, including the high costs associated with cleanup and the possibility of environmental deterioration as a result of the release of substances used in restorative processes. Following that, emphasis is placed on the utilisation of biological processes for soil healing that are benign to the environment [6]. To better reflect the types of heavy metals and plants often reported for phytoremediation, the Scopus keyword search string heavy AND metals OR mercury OR zinc OR cadmium OR arsenic OR phytoextraction OR 
phytoremediation OR phytostabilization OR phytovolatilization OR rhizofiltration was input into the database yielding 1882 journal articles. The VOSViewer software is used to create the keyword co-occurrence of the documents, which is displayed in Fig. 1. The study's goal is to conduct a complete bibliometric assessment of the research landscape Five clusters were discovered and it appears that cadmium is the most often heavy metal studied in phytoremediation followed by lead copper, chromium and zinc. Accumulation of heavy metals in the root is the most reported followed by stem and leaves (Fig. 1).

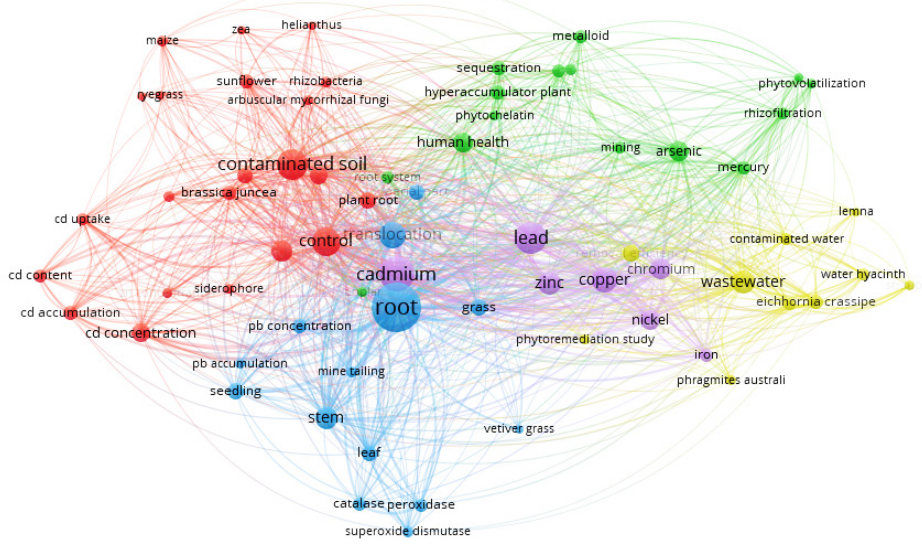

Fig. 1. Bibliometric map generated by VOSViewer based on Scopus Collection. The Keywords were heavy AND metals OR mercury OR zinc OR cadmium OR arsenic OR phytoextraction OR phytoremediation OR phytostabilization OR phytovolatilization OR rhizofiltration. The size of each circle correlates with the occurrences in 1882 articles of Scopus indexed from 1995 to 2022 . The most frequent keyword is root with 771 occurrences followed by cadmium (76), copper (65), and zinc (56).

When it comes to bioremediation, it is defined as the process by which pollutants are biologically removed or transformed under regulated circumstances, resulting in a state that is benign or levels that are below the concentration limits established by regulatory authorities [7]. Phytoremediation is a technology that can be applied to a variety of reclamation treatments because it does not interact with the environment, requires minimal labour, and is, therefore, less expensive than traditional physicochemical approaches when compared to those procedures. When compared to those procedures, phytoremediation is less expensive than traditional physicochemical approaches [6]. Some of the most common sources of soil contamination are heavy metals, sewage, and industrial waste, as well as significant volumes of fertilisers and pesticides sprayed to agricultural fields. In terms of soil contamination, heavy metals are the primary culprit $[8,9]$.

Plants have the ability to absorb and/or decompose inorganic and organic toxins, which needs a better understanding of environmentally friendly strategies for the rehabilitation of polluted soils and water [10]. As a result of the compelling need to develop new technology for recycling irrigated and groundwater, the technical and financial advantages of using both plants and associated bacteria for this goal have been identified [11]. When heavy and harmful metals are discovered in soil, plants can be utilised to sterilise the soil in an environmentally friendly manner. Recently, a dependable strategy for coping with a wide range of soil conditions was discovered and implemented. It is possible to employ natural mutations in plants and soil microbes to reduce the damaging or clustering effects of contaminants in the environment [10]. It has been shown that some plants, known as hyperaccumulators, are particularly resistant to the effects of heavy metal contamination. The ability to accumulate and transfer soil contaminants is what they are best at, as the name implies [12]. In the event that you're seeking something that's simple to modify, affordable, and capable of protecting the environment, naturally mutated greenery is a fantastic alternative. These organisms were not only useful to the environment, but they were also beneficial to human beings [13]. Because of the ecological, practical, and cost-effective features of plant-based phytoremediation, which is a new and emerging treatment method for environmental contamination, it is expected to be a long-term solution in the near future. However, challenges such as anthropogenic contamination have hampered the usefulness of this environmentally friendly technique. Therefore, it is vital to conduct an objective evaluation of the strategy's potential limitations. This research will shed light on the topic of phytoremediation and make recommendations for its future application.

\section{Contamination of soil by heavy metals}

The phrases "contamination" and "pollution" are frequently used improperly interchangeably in several literature reviews, which is not uncommon. Pollution, on the other hand, can be separated from contamination, which simply refers to the existence of substances that are potentially harmful at a specific intensity or quantity. Pollution is described as contamination that has a negative biological influence on human populations [14]. Decontamination of heavy metal-contaminated soil is a complex, expensive, and time-consuming technique that takes a long time [14]. The lithosphere is composed of heavy metals such as chromium $(\mathrm{Cr})$, thallium $(\mathrm{Ti})$, lead $(\mathrm{Pb})$, cadmium $(\mathrm{Cd})$,arsenic (As), and mercury $(\mathrm{Hg})$. These metals cannot be destroyed or eliminated from the environment, but when present in significant quantities, they can poison plants.

Because the phrase "bioremediation" is usually used when the amount of contaminants is in the middle of the range between low and moderate, the term "contamination" is acceptable for topics connected to bioremediation [3,9]. Heavy metals are classified into two types: vital metals and non-essential metals. Essential, basic, or microelements are metals that are required for chemical processes in living organisms. Manganese $(\mathrm{Mg})$, copper $(\mathrm{Cu})$, cobalt $(\mathrm{Co})$, and zinc $(\mathrm{Zn})$ are examples of essential, basic, or microelements $(\mathrm{Zn})$. Non-essential metals may have unknown activities in animal physiology; for example, lead $(\mathrm{Pb})$, mercury $(\mathrm{Hg})$, cadmium $(\mathrm{Cd})$, and arsenic $(\mathrm{As})$ are all metals with unclear functions $[2,2,14]$. Nonetheless, a surprising number of nonessential elements have been discovered to have exciting or motivating effects in plants, especially when administered at low concentrations; one notable example is $\mathrm{Cd}$, which has been found to have stimulation effects in barley seedlings [15].

\section{Biological remediation contaminated site}

Using plants, microbial enzymes, microorganisms, or enzymes generated by plants, hazardous compounds can be degraded or removed from the environment through the process of bioremediation. As a developing technology, it has the potential to aid in the treatment of environmental waste when used in conjunction with other approaches, whether chemical or physical, in the treatment of environmental waste $[5,14]$. In order to do this, actinomycetes, bacteria, fungal spores, and earthworms are all utilised as a part of an integrated strategy. Phytoremediation, a subset of bioremediation, is a technique in which plants and herbs are utilised to eliminate toxins from soil and water [16]. It is the most accurate method of eliminating toxic substances from groundwater, surface water, sediment, damaged 
soil, and the environment that plant-mediated bioremediation may be utilised. By using higher-living species in the ecosystem, toxin-containing chemicals are removed from groundwater and surface water, as well as sediment, polluted soil, and the atmosphere [17,18].

Soil acts as a final acceptor for substances distributed into the natural environment as a result of various human activities such as agriculture. Both inorganic and organic contaminants have the potential to accumulate in soil $[10,13,19]$, providing serious concerns to the population and environmental health. As a result of bioaccumulation and biomagnification processes, these chemicals have the potential to disrupt the chemical, physical, and biological balance of the soil and enter the food chain, where they have the potential to make their way into the human food supply. The environment is said to be contaminated when the concentration of toxins in water, air, or soil exceeds a legally specified standard value [20]. According to [20], environmental remediation is critical for improving people's health and preserving the ecosystem for future generations. A wide spectrum of pollutants may be found in soil, air, and water, and they can be naturally occurring or anthropogenically manufactured. Both natural pollution releases and poorly managed human activities are to blame for biological and chemical pollution created by inorganic and organic substances $[21,22]$. This pollution offers a significant hazard to soil reuse.

Many different inorganic substances have been detected in polluted soils that have the potential to alter their natural equilibrium, with heavy metals being the most common. There is no widely agreed definition of heavy metals in aspects of their physicochemical characteristics; nevertheless, they are described as such if they exhibit characteristics such as ductility, conductivity, ligand specificity, and an atomic number greater than 20; otherwise, they are described as non-elements [2]. Metals are naturally occurring earth constituents, but their predominance has expanded dramatically since the beginning of the Industrial Revolution when the first steam engine was created. Despite the fact that heavy metals occur naturally throughout the earth's crust, several heavy metals, including Cadmium (Cd), Copper (Cu), Chromium (Cr), Lead $(\mathrm{Pb})$, Mercury (Hg), Zinc (Zn), Nickel (Ni), and the metalloid arsenic (As), are widely used in industry and agriculture and are thus released into the environment. In the tanning industry, for example, effluent from tanneries conveys a number of foulsmelling chemical compounds such as hydrogen sulphide, ammonia, and chromium [5].

Various sources, such as the petrochemical industry and automobile traffic, contribute to the release of metals into the environment [23]. Toxins must be bioavailable and ready to be absorbed by the roots for phytoremediation treatments to be effective. Metal bioavailability is determined by their solubility in soil. Heavy metals in soil, such as cadmium, zinc, lead, nickel, and copper, have been demonstrated to be detrimental to humans and animals $[6,24]$. Cadmium can be found in soil due to a variety of natural and man-made causes, including mining. Natural occurring element lead is present in the lithosphere and has a wide range of industrial, agricultural, and domestic applications. Lead is used in the production of lead-based paint. People, animals, and the environment are all at risk from lead poisoning. When compared to other pollutants, it has a longer duration of existence in the soil due to its poor solubility. It has an adverse effect on human health as a result of this. As a result, it is no longer suitable for use in the production of gasoline [25-27].

Despite the fact that zinc is a naturally occurring metal in soil, human inputs such as fertilisers lead to greater soil concentrations of the element. $\mathrm{Zn}$ is mobilised in soil in response to changes in soil factors such as $\mathrm{pH}$, cations exchange, and the presence of other chemical components [28]. Natural copper may be found in abundance in a variety of environments, including soil, water, rocks, and minerals. The widespread usage of this metal in human activities indicates that it holds a great deal of potential in the future. Copper ion $(\mathrm{Cu})$ forms bonds with both inorganic and organic molecules in soil and sediment, and the rate at which this reaction occurs is controlled by the $\mathrm{pH}$, redox potential, and anions present in the environment [29]. Nickel is a naturally occurring metal that may be found in minute quantities in both sand and seawater. Due to its widespread usage in a wide range of industrial and technological applications, nickel has accumulated in the environment at an increasing rate.

The capacity of the soil to retain nickel is impacted by the texture of the soil, the amount of organic matter present, the existence of mineral crystals, the $\mathrm{pH}$ of the soil, its water content, and the presence of hydroxides [28,30]. Most vanadium released into the environment is due to human activities, which account for the vast majority. Arsenic is a metalloid that may be found in abundance in the Earth's crust, seas, lakes, and rivers. It is also found in small amounts in the atmosphere [31,32]. The release of arsenic into the environment occurs as a result of both natural and human-caused activities [33,34]. Because of the many ionic forms of As (the most harmful), their toxicity, bioavailability, and transport are all affected differently. Chromium may be found in large quantities in the Earth's crust, lakes, rivers, and oceans. Despite the fact that chromium exists in three oxidation states, the trivalent and hexavalent forms are the most stable and commercially significant [35]. As a result of industrial pollution, chromium levels in soil and water have risen significantly in recent years $[35,36]$.

Mercury is liquid at room temperature and is classed as an element, inorganic, and organic contaminant due to its occurrence in soil as an organic and inorganic compound [37,38]. It can be released into the environment in a variety of ways, including volcanic exhalations and thermal springs, to mention a few. The presence of this metal has increased because of anthropogenic actions such as copper and zinc extraction, the burning of fossil fuels and waste, the use of fertilisers in cultivation, and the use of agricultural pesticides [21,36]. Through biomagnification, toxic methylated mercury compounds can enter the food chain and be ingested by people [39].

\section{Bioremediation}

Biological remediation is defined as "the use of living creatures to clean up oil spills or to remove other pollutants from soil, water, or wastewater; the use of organisms such as non-harmful insects to eliminate agricultural pests or to counteract illnesses of trees, plants, and garden soil" (US EPA, United States Environmental Protection Agency). Specifically, bioremediation, according to [40], is "the process by which organic wastes are biologically destroyed under controlled conditions to a benign state, or to levels below concentration limits defined by regulatory agencies." Other than enzymatic degradation of organic pollutants by microorganisms such as bacteria and fungi, several terrestrial and aquatic plants are efficient in eliminating contaminants from aquatic bodies and soils by absorbing them through the roots and storing them as nutrients in the foliage. As a result, whether the microorganisms used in the restoration process are indigenous or imported, the process will be more successful. 


\section{Phytoremediation}

According to [41], "phytoremediation" was first used to refer to a strategy that relies on plants to either remove toxins from soil and water or render them harmless [42,43]. This phrase was first used in 1991 after decades of research. In the current climate, phytoremediation is garnering the attention of worldwide stakeholders, not only because of its potential application in soil remediation but also because of its ability to enhance the management of connected wastes and contaminants. Because contamination of the environment causes major dangers to human health and has an influence on the environment, phytoremediation is currently gaining attention from a wide range of stakeholders throughout the world. Although a multitude of physical and chemical procedures can be used to repair the various matrices, each method comes with its own set of limitations and requirements. Expensive, time-consuming methods that have been in use for millennia have the potential to upset the natural microbiota by modifying the soil's physical properties. When it comes to long-term costs, phytoremediation is being regarded as a new alternative [44].

In phytoremediation, green plants can remove, uptake, or render harmless heavy metals, organic chemicals, and radioactive substances in soil or water because of their transport capacity and ability to accumulate toxins. Plants like Thlaspi caerulescens, Salix spp., or a combination of the two are commonly employed in phytoremediation, as are herbs like Thlaspi caerulescens [45]. Aside from that, phytoremediation helps to avoid the excavation of polluted regions, reduces the risk of toxins dispersal, and is suitable for the decontamination of sites contaminated by a variety of pollutants [34]. The nature of the pollutant, its bioavailability, soil conditions, and the plant species utilised all have an impact on the mechanisms and efficiency of phytoremediation. When it comes to phytoremediation procedures, plants designated as "hyperaccumulators" are regarded to be more effective than other plants. Despite the fact that these plants have the potential to withstand and absorb metals or organic chemicals prevalent in soil, such as PAHs, they have a poor rate of biomass production compared to other plants [46].

The amount of biomass produced by the plant has an impact on the efficiency with which pollutants are extracted: a large amount of biomass is capable of absorbing a large number of metals or organic compounds, including PAHs, but it will take many harvests to completely remove the plants from the environment. Consequently, the overall cost of the entire operation, including waste biomass disposal, incineration, and composting, will be determined by the number of harvests that take place over time [42,46,47]. Although there are some drawbacks to phytoremediation (for example, the slowness of the process and the fact that the affected area of the land is adjacent to the root, as well as the fact that several species cannot be planted in heavily polluted areas), it is applicable to a wide range of remediation treatments. Its benefits stem from the fact that it does not harm the environment and, as a result of the plant cover, adds aesthetic value to the treated land. It also requires little labour, making it a cost-effective solution.

It is practicable to utilise in situ and is well received by the local populace. Biomass collected can be used in renewable energy fields such as biofuel production [48], waste reduction [45], and waste reduction $[36,45,49]$.

\section{Phytoextraction}

On-site remediation of polluted soils via phytoextraction is becoming more common $[39,50]$. The roots take in the chemicals, which are then transferred to the shoots and leaves, where they are concentrated [51]. This approach relies on plants that can both accumulate pollutants and produce a considerable amount of biomass. Thlaspi caerulescens, Alyssum bertholoniae, Arabidopsis halleri, and Brassica spp. can be used to minimise pollution by accumulating pollutants but producing minimal biomass (e.g., Thlaspi caerulescens, Alyssum bertholoniae, and Arabidopsis halleri) [52,53]. When a plant is harvested, it removes pollutants from the environment, and the process continues with incineration and disposal [48]. It is an environmentally friendly technology that has several advantages, one of which is that it does not harm or alter the terrain. This ensures that conservation and, consequently, the ecology, will be conserved.

Heavy metals can be extracted from soil, sediment, and water using phytoextraction, the most common phytoremediation process. For its low cost, phytoextraction is considered to be the most promising technique available in terms of business viability. Even if it has several advantages, metals phytoextraction is limited by various variables, according to the authors [42,54]. Metal bioavailability in the rhizosphere is reduced, roots absorb metal at a lesser rate, and metals are retained within the roots. Some plant species have been shown to be able to perform phytoextraction activities in the presence of heavy metals in a number of investigations. According to [26], phytoextraction capability of the perennial herb Arundo donax against a Cdcontaminated soil was $2.92-4.02 \mathrm{mg} / \mathrm{kg} \mathrm{Cd}$ in leaves and rhizomes, respectively, in leaves and rhizomes. Experiments on Arundo donax and Trichoderma harzianum showed that phytoextraction of $\mathrm{Cd}$ was increased in the leaves ( 20 per cent) and rhizomes ( 50 per cent) of the plant.

\section{Phytostabilization}

Pollutants are immobilised in the root system as a result of absorption by the roots or rhizosphere precipitation. As a result of this method, pollutant mobility is reduced, which prevents contaminants from migrating into groundwater and limits their bioavailability in the food supply chain. Authors who have written about this topic include $[55,56]$. Metal-resistant plants are utilised to repopulate areas that have been contaminated by metals. There is a lot of evidence that phytostabilization can help with heavy metal treatment, such as lead, arsenic, cadmium, copper, and zinc. All of these advantages are the result of changes in soil chemistry caused by plant presence. Metal precipitation on plant roots can either increase or inhibit metal absorption $[57,58]$. No soil remediation method will be effective in eliminating toxins unless the plant is removed. This approach was used to revegetate highly acidic mine soils in southern China, with the $\mathrm{pH}$ of the soil improving from 2.6 to 3.0 following two years of phytostabilization. According to the study's findings, aided phytostabilization could be a useful technique for reclaiming mine soils in the future.

\section{Phytovolatilization}

The xylem of a plant transfers contaminants from the root to the aerial sections, where they are less harmful to the surrounding environment. Pollutants are not removed, as demonstrated by [59], but rather transported from one compartment to another. [6] demonstrated that contaminants are not removed but rather transported from one compartment to another, as demonstrated by $[42,60]$. These compounds in the plant's air compartment are likely to diffuse to the leaves and shoots via other areas of the plant. The application of this technique can lessen the toxicity of a pollutant, but the most significant disadvantage is the possibility that a modified material, which is still potentially dangerous, will be discharged into the atmosphere and then re- 
enter the ecosystem. Chemical contaminants in soil, sediment, or water can be treated by phytovolatilization. Organic pollutants such as tetrachloroethane, trichloromethane, and tetrachloromethane can be treated via phytovolatilization. According to [26,37], metals with significant volatility, such as mercury and selenium, are the exceptions to this norm.

In the long run, the mercury ion can be converted into a less hazardous form and released back into the environment. Because mercury can collect on lakes and oceans and generate methylmercury as a result of anaerobic bacteria's activities, there is a major risk of further mercury emissions into the environment as a result of this method [37,42]. The amount of mercury emitted from leaf tissue is significantly influenced by the amount of light and air temperature available [38]. There were five different species of plants studied in this study, each of which was grown in soil contaminated with mercury at concentrations ranging from $450 \mathrm{mg}$ to $1605 \mathrm{mg}$. The plants studied were Lepidium latiflorum, Caulanthus sp., Artemisia douglasiana, Fragaria vesca, and Eucalyptus globulus. The mercury emissions from all plant species were orders of magnitude lower at night than they were during the day, with the exception of Caullanthus sp., which had much higher mercury emissions during the day [37].

\section{Rhizofiltration}

Rhizofiltration is a technique that utilises adsorption and precipitation on the roots to remove organic and inorganic pollutants from groundwater, surface water, and wastewater [61]. Terrain and aquatic plants can be used in situ and ex-situ, but terrestrial plants are preferred since they have a more established root and fibre system, providing a larger surface area for absorption. In addition to being metal-resistant, the plants used must have a large absorption surface and the ability to withstand hypoxia (e.g. Salix spp, Populus spp, Brassica spp). As a result, this method has drawbacks, such as the need to modify $\mathrm{pH}$, the requirement of first growing in a greenhouse, and the necessity for multiple harvests, as well as the eventual disposal of plants (49).

It is demonstrated in a system (which maintains heavy metals at the root level and harvests the root once it has been saturated with these elements) can be used to remove heavy metals from plants [62]. This technology can also be used to eliminate radioactive contaminants from the environment. The use of sunflowers to remove radioactive pollutants (caesium and strontium) from the Chernobyl nuclear power plant in Ukraine has proven to be effective. According to the findings, sunflowers are capable of accumulating both $\mathrm{Cs}$ and $\mathrm{Sr}$, with the former remaining in the roots and the latter migrating into the plant's shoots and blooms [63]. Rhizofiltration has been demonstrated to clean up uranium-contaminated groundwater using sunflower (Helianthus annuus) and bean (Phaseolus vulgaris) as the principal plants [61]. In this experiment, three authentic groundwater samples were compared to a solution that had been intentionally contaminated. The sunflower was successful in removing more than $80 \%$ of the uranium present in the artificial solution and groundwater, with the remaining uranium content in the treated water being less than $30 \%$ of the original concentration (US EPA drinking water limit). Uranium removal efficiency ranged from 60 per cent to 80 per cent in the case of the bean, depending on the strain. Using the two plant cultivars under investigation, the greatest amount of uranium removed via rhizofiltration was 90 per cent, with a large proportion of the uranium accumulating at the plant's root level.

\section{Plants used in phytoremediation}

The elements $\mathrm{N}, \mathrm{P}, \mathrm{K}, \mathrm{Ca}$, and $\mathrm{Mg}$ are all essential nutrients that can be absorbed from the soil via the plant's root system, as can a number of additional nutrients $(\mathrm{N} F \mathrm{Fe} \mathrm{Cu} \mathrm{B} \mathrm{Mo})$ and micronutrients. Transport proteins connected to the cell membrane can function passively, as they do during transpiration, or actively, as they do in the case of the former type of transport protein. The apoplast and the symplast are both responsible for transporting these components into the plant. To carry dissolved nutrients from the roots to the rest of the plant, the xylem vascular system must be in operation. Plants take up non-essential inorganic chemicals, such as heavy metals, that are considered to be pollutants, in addition to the nutrients that they require to survive. $\mathrm{Cu}, \mathrm{Zn}$, and $\mathrm{Mn}$, which are generally considered nutrients by humans, are retained or stabilised by plants through a variety of mechanisms. If present in excessive concentrations, these elements can become harmful to humans. Beyond the fact that they may store or digest toxins, plants can also be used in the restoration of polluted soils because of their ability to limit the amount of garbage that must be disposed of in landfills, which is beneficial for the environment. Toxins can be absorbed by plants through their roots and stored in the vacuoles of their leaves until the leaves fall to the ground or are removed, at which point the toxins are released into the surrounding environment.

The ability of a plant to absorb relevant toxins is a significant element to consider when selecting the optimal plant for phytoremediation applications. Metalophytes, in contrast to non-hyperaccumulator species, can survive heavy metal concentrations up to 100 times greater than nonhyperaccumulator species $[12,59]$. Metalophytes are plants that can withstand heavy metal concentrations that are up to 100 times greater than non-hyperaccumulating species. It is possible to distinguish between obligatory and non-obligatory metallophytes based on the presence of specific metals in the environment. Other organisms, such as Brassica juncea, Helianthus annuus, Festuca arundina, and Populus spp., have developed systems that allow them to endure harmful metal concentrations. These processes have been created to allow them to tolerate dangerously high metal concentrations. Some plants, such as those in the Brassicaceae family, are known to be hyperaccumulators [64]. The phytochelatins of Thlaspi caerulescens can chelate metal ions, allowing them to be stored in vacuoles and lowering their concentration within the cell. The research on Thlaspi caerulescens (a hyperaccumulator) and Thlaspi arvense (a non-hyperaccumulator) were used in the experiments to determine zinc absorption and transport [12].

\section{The financial return on investment}

According to the Environmental Protection Agency, the industry of phytoremediation has not yet developed to the same level in Europe as it has in the United States, where revenues exceeded \$300 million in 2007 according to the Environmental Protection Agency. [21] Campos and colleagues (2008) developed one of the new methods, phytoremediation, which was subjected to a field study by the United States Environmental Protection Agency (US EPA) in 2001. The findings of this review clearly indicate that phytoremediation is a fiscally viable alternative [65]. Over the last several years, conventional environmental remediation methods have fallen out of popularity in Europe, with plant-based alternatives gaining ground as they are found to be both more ecologically friendly and cost-effective than their predecessors. Early studies from 1999 and 2000 demonstrated that phytoremediation is extremely cost-effective when compared to conventional innovations (Table 1), such as electrochemical separation, harvesting and landfill disposal of 
contaminated soil, vitrification of contaminated soil at high temperatures, soil washing with water and solubilizing agents, and solidification through the use of stabilising agents.

The removal of toxins from the environment can be accomplished through the use of plants and other natural resources, making phytoremediation less expensive than traditional remediation approaches. Plant roots have the ability to stabilise soil and avoid contamination from runoff and windblown dust, which are both important aspects of soil management. Phytoremediation can be employed both in situ and ex-situ, depending on the situation. These approaches are more expensive than in situ phytoremediation because they require excavation of the ground, off-site storage of contaminated soil, waterlogged soil, and in situ coating for neutralisation of the contaminated soil [66]. In order to use in-situ techniques, it is vital to develop standards that are both simple to apply and minimal in maintenance costs (Table 1). In situ procedures can be considered a reliable and solar-powered technique for the treatment of relatively contaminated soil over large areas if the plants are carefully chosen and agronomic methods are in place to ensure those trace elements are transferred correctly to plants from the soil [28].

Table 1. Cost of phytoremediation when compared to others (adapted from [67]).

\begin{tabular}{lll}
\hline Methods & $\begin{array}{l}\text { Cost } \\
\text { (USD\$/ton) }\end{array}$ & Supplementary Effort/Expenditure \\
\hline Land treatment & $100-500$ & Transport/Excavation/Monitoring \\
Chemical approach & $100-500$ & Recycling of contaminants \\
Vitrification & $75-450$ & Long-term monitoring \\
Electrokinetic & $20-200$ & Monitoring \\
Phytoremediation & $5-40$ & Monitoring
\end{tabular}

\section{Conclusions and future perspectives}

Metal and organic damaged soils can be rectified utilising phytoremediation technologies, which have been discussed in detail here. Phytoremediation was considered a new and novel method when it was initially offered 15-20 years ago. Despite the fact that European researchers have lately crossed the information gap that existed between them and their American counterparts, there is still significant variance in how phytoremediation is done in the United States and Europe [68]. Companies in nations such as the United States and Canada are attempting to use phytoremediation techniques to tackle environmental pollution [42]

Conventional methods are more effective than phytoremediation at removing pollutants, and their application times are shorter. Conventional techniques, on the other hand, are more expensive and alter the qualities of the soil and groundwater. Phytoremediation might be a desirable option since it is a clean and cost-effective alternative to traditional physicochemical procedures (excavation and landfilling; washing; vitrification; electrochemical separation). While phytoremediation requires less expert involvement and can be used for extended periods of time, it also requires less waste to be disposed of in landfills and does not release potentially hazardous substances into the environment [42]. Many studies have demonstrated the environmental damage caused by landfills and other petrochemical complexes. Polluted soils must be rehabilitated due to a scarcity of available land and the compelling need to utilise newly created areas in both developed and developing countries. It would be a good idea to intervene in areas of Italy that have been extensively contaminated and need to be cleaned up in order to be converted into productive areas. The use of plants in bioremediation can provide numerous benefits, including cogeneration of energy and the production of biofuels following the removal of pollutants; metals recovered from plant incineration can be used as raw materials in industrial operations. Using genetically modified plants can provide additional benefits, but their use and risks should be carefully considered on a case-by-case basis rather than being generalised [59].

\section{CONCLUSION}

Phytoremediation is a bioremediation technique that uses plants to reduce the toxicity of heavy metals either by uptake and the subsequent immobilization in various plants organs or the use of symbiotic microorganisms at the roots to biotransformed the heavy metals into a less soluble or less toxic form. In terms of both economic and environmental benefits, there is much question that phytoremediation techniques can be a viable alternative to physicochemical treatments. A better understanding of the possibilities and limitations of phytoremediation will almost certainly lead to an increase in its application for soil remediation in the near future.

\section{REFERENCES}

1. Agnello AC, Bagard M, van Hullebusch ED, Esposito G, Hugueno D. Comparative bioremediation of heavy metals and petroleum hydrocarbons co-contaminated soil by natural attenuation, phytoremediation, bioaugmentation and bioaugmentation-assisted phytoremediation. Sci Total Environ. 2016;563-564:693-703.

2. Tchounwou PB, Yedjou CG, Patlolla AK, Sutton DJ. Heavy metals toxicity and the environment. Mol Clin Env Toxicol. 2012;101:133-64.

3. Dadar M, Adel M, Ferrante M, Nasrollahzadeh Saravi H, Copat C, Oliveri Conti G. Potential risk assessment of trace metals accumulation in food, water and edible tissue of rainbow trout (Oncorhynchus mykiss) farmed in Haraz River, northern Iran. Toxin Rev. 2016;35(3-4):141-6.

4. Chaney RL, Broadhurst CL, Centofanti T. Phytoremediation of Soil Trace Elements. Trace Elements in Soils. 2010. 311-352 p.

5. Chauhan S, Das M, Nigam H, Pandey P, Swati P, Tiwari A, et al. Implementation of phytoremediation to remediate heavy metals from tannery waste: A review. Adv Appl Sci Res. 2015;6(3):11928.

6. Ali H, Khan E, Sajad MA. Phytoremediation of heavy metalsConcepts and applications. Chemosphere. 2013;91(7):869-81.

7. Varjani SJ, Upasani VN. Biodegradation of petroleum hydrocarbons by oleophilic strain of Pseudomonas aeruginosa NCIM 5514. Bioresour Technol. 2016;222:195-201.

8. Conte P, Agretto A, Spaccini R, Piccolo A. Soil remediation: Humic acids as natural surfactants in the washings of highly contaminated soils. Environ Pollut. 2005;135(3 SPEC. ISS.):51522.

9. Kavamura VN, Esposito E. Biotechnological strategies applied to the decontamination of soils polluted with heavy metals. Biotechnol Adv. 2010;28(1):61-9.

10. Burges A, Epelde L, Blanco F, Becerril JM, Garbisu C. Ecosystem services and plant physiological status during endophyte-assisted phytoremediation of metal contaminated soil. Sci Total Environ. 2017;584-585:329-38

11. Burken JG, Schnoor JL. Phytoremediation: Plant uptake of atrazine and role of root exudates. J Environ Eng. 1996;122(11):958-63.

12. Deniau AX, Schat H, Aarts MGM. Genetics and genomics of the heavy metal hyperaccumulator model species thlaspi caerulescens. Genes Genomes Genomics. 2007;1(1):81-8.

13. Fontana S, Wahsha M, Bini C. Preliminary observations on heavy metal contamination in soils and plants of an abandoned mine in Imperina Valley (Italy). Agrochimica. 2010;54(4):218-31.

14. Koptsik GN. Problems and prospects concerning the phytoremediation of heavy metal polluted soils: A review. Eurasian Soil Sci. 2014;47(9):923-39.

15. Nunes da Silva M, Mucha AP, Rocha AC, Silva C, Carli C, Gomes $\mathrm{CR}$, et al. Evaluation of the ability of two plants for the 
phytoremediation of Cd in salt marshes. Estuar Coast Shelf Sci. 2014;141:78-84.

16. Isaac P, Martínez FL, Bourguignon N, Sánchez LA, Ferrero MA. Improved PAHs removal performance by a defined bacterial consortium of indigenous Pseudomonas and actinobacteria fromPatagonia, Argentina. Int Biodeterior Biodegrad. 2015;101:23-31.

17. Shimp JF, Erickson LE. Beneficial Effects of Plants in the Remediation of Soil and Groundwater Contaminated with Organic Materials. Crit Rev Environ Sci Technol. 1993;23(1):41-77.

18. Thomas KV, Balaam J, Barnard N, Dyer R, Jones C, Lavender J, et al. Characterisation of potentially genotoxic compounds in sediments collected from United Kingdom estuaries. Chemosphere. 2002;49(3):247-58.

19. Albergaria JT, Alvim-Ferraz MDCM, Delerue-Matos C. Remediation of sandy soils contaminated with hydrocarbons and halogenated hydrocarbons by soil vapour extraction. J Environ Manage. 2012;104:195-201.

20. USEPA. 2012 Edition of the Drinking Water Standards and Health Advisories. 2012 Ed Drink Water Stand Health Advis. 2012;

21. Campos VM, Merino I, Casado R, Pacios LF, Gómez L. Review. Phytoremediation of organic pollutants. Span J Agric Res. 2008;6(SPEC. ISS.):38-47.

22. Yin H, Tan Q, Chen Y, Lv G, He D, Hou X. Polycyclic aromatic hydrocarbons (PAHs) pollution recorded in annual rings of gingko (Gingko biloba L.): Translocation, radial diffusion, degradation and modeling. Microchem J. 2011;97(2):131-7.

23. Varjani SJ, Upasani VN. A new look on factors affecting microbial degradation of petroleum hydrocarbon pollutants. Int Biodeterior Biodegrad. 2017;120:71-83.

24. Duffus JH. Erratum: "Heavy metals" - A meaningless term? IUPAC technical report (Pure and Applied Chemistry (2002) 74 (793-807)). Pure Appl Chem. 2003;75(9):1357.

25. Hernberg S. Lead poisoning in a historical perspective. Am J Ind Med. 2000;38(3):244-54.

26. Kos B, Grčman H, Leštan D. Phytoextraction of lead, zinc and cadmium from soil by selected plants. Plant Soil Environ. 2003;49(12):548-53.

27. Guo Z-H, Miao X-F. Growth changes and tissues anatomical characteristics of giant reed (Arundo donax L.) in soil contaminated with arsenic, cadmium and lead. J Cent South Univ Technol Engl Ed. 2010;17(4):770-7.

28. Fernández S, Poschenrieder C, Marcenò C, Gallego JR, JiménezGámez D, Bueno A, et al. Phytoremediation capability of native plant species living on $\mathrm{Pb}-\mathrm{Zn}$ and $\mathrm{Hg}$-As mining wastes in the Cantabrian range, north of Spain. J Geochem Explor. 2017;174:1020.

29. Goswami S, Das S. Copper phytoremediation potential of Calandula officinalis $\mathrm{L}$. and the role of antioxidant enzymes in metal tolerance. Ecotoxicol Environ Saf. 2016;126:211-8.

30. Andreolli M, Lampis S, Poli M, Gullner G, Biró B, Vallini G. Endophytic Burkholderia fungorum DBT1 can improve phytoremediation efficiency of polycyclic aromatic hydrocarbons. Chemosphere. 2013;92(6):688-94

31. Vamerali T, Bandiera M, Coletto L, Zanetti F, Dickinson NM, Mosca G. Phytoremediation trials on metal- and arseniccontaminated pyrite wastes (Torviscosa, Italy). Environ Pollut. 2009;157(3):887-94.

32. Weelink SAB, van Eekert MHA, Stams AJM. Degradation of BTEX by anaerobic bacteria: Physiology and application. Rev Environ Sci Biotechnol. 2010;9(4):359-85.

33. Visoottiviseth P, Francesconi K, Sridokchan W. The potential of Thai indigenous plant species for the phytoremediation of arsenic contaminated land. Environ Pollut. 2002;118(3):453-61.

34. Mudhoo A, Sharma SK, Lin ZQ, Dhankher OP. Phytoremediation of arsenic-contaminated environment an overview. Green Chem Environ Sustain. 2010;127-49.

35. Sreeram KJ, Ramasami T. Sustaining tanning process through conservation, recovery and better utilization of chromium. Resour Conserv Recycl. 2003;38(3):185-212.

36. Tong K, Zhang Y, Liu G, Ye Z, Chu PK. Treatment of heavy oil wastewater by a conventional activated sludge process coupled with an immobilized biological filter. Int Biodeterior Biodegrad. 2013;84:65-71.
37. Leonard TL, Taylor Jr. GE, Gustin MS, Fernandez GCJ. Mercury and plants in contaminated soils: 1 . Uptake, partitioning, and emission to the atmosphere. Environ Toxicol Chem. 1998;17(10):2063-71.

38. Pacyna EG, Pacyna JM, Steenhuisen F, Wilson S. Global anthropogenic mercury emission inventory for 2000. Atmos Environ. 2006;40(22):4048-63.

39. Li Y-M, Chaney R, Brewer E, Roseberg R, Angle JS, Baker A, et al. Development of a technology for commercial phytoextraction of nickel: Economic and technical considerations. Plant Soil. 2003;249(1):107-15.

40. Macaulay BM, Rees D. Bioremediation of oil spills: a review of challenges for research advancement. Ann Env Sci. 2014;8(March):9-37.

41. Vidali M. Bioremediation. An overview. Pure Appl Chem. 2001;73(7):1163-72.

42. Sharma P, Pandey S. Status of phytoremediation in world scenario Int J Env Bioremed Biodegrad. 2014;2(4):178-91.

43. Kumar A, Bisht BS, Joshi VD, Dhewa T. Review on bioremediation of polluted environment: A management tool. Int J Environ Sci 2011;1(6):1079-93.

44. Yu X-Z, Gu J-D. Uptake, metabolism, and toxicity of methyl tertbutyl ether (MTBE) in weeping willows. J Hazard Mater. 2006;137(3):1417-23.

45. Tahir U, Yasmin A, Khan UH. Phytoremediation: Potential flora for synthetic dyestuff metabolism. J King Saud Univ-Sci. 2015;

46. Van Oosten MJ, Maggio A. Functional biology of halophytes in the phytoremediation of heavy metal contaminated soils. Environ Exp Bot. 2015;111:135-46.

47. Alkorta I, Garbisu C. Phytoremediation of organic contaminants in soils. Bioresour Technol. 2001;79(3):273-6.

48. Jiang Y, Lei M, Duan L, Longhurst P. Integrating phytoremediation with biomass valorisation and critical element recovery: A UK contaminated land perspective. Biomass Bioenergy. 2015;83:32839.

49. Nesterenko-Malkovskaya A, Kirzhner F, Zimmels Y, Armon R. Eichhornia crassipes capability to remove naphthalene from wastewater in the absence of bacteria. Chemosphere. 2012;87(10):1186-91.

50. Grčman H, Velikonja-Bolta Š, Vodnik D, Kos B, Leštan D. EDTA enhanced heavy metal phytoextraction: Metal accumulation, leaching and toxicity. Plant Soil. 2001;235(1):105-14.

51. Lasat MM. Phytoextraction of metals from contaminated soil: A review of plant/soil/metal interaction and assessment of pertinent agronomic issues. J Hazard Subst Res. 2000;2(5):1-25.

52. Gerhardt KE, Huang X-D, Glick BR, Greenberg BM Phytoremediation and rhizoremediation of organic soil contaminants: Potential and challenges. Plant Sci. 2009;176(1):2030

53. Cunningham SD, Ow DW. Promises and prospects of phytoremediation. Plant Physiol. 1996;110(3):715-9.

54. Chandra S, Sharma R, Singh K, Sharma A. Application of bioremediation technology in the environment contaminated with petroleum hydrocarbon. Ann Microbiol. 2013;63(2):417-31.

55. Yang S-X, Liao B, Yang Z-H, Chai L-Y, Li J-T. Revegetation of extremely acid mine soils based on aided phytostabilization: A case study from southern China. Sci Total Environ. 2016;562:427-34.

56. Zhao L, Li T, Yu H, Zhang X, Zheng Z. Effects of $[\mathrm{S}, \mathrm{S}]$ ethylenediaminedisuccinic acid and nitrilotriacetic acid on the efficiency of $\mathrm{Pb}$ phytostabilization by Athyrium wardii (Hook.) grown in Pb-contaminated soils. J Environ Manage. 2016;182:94100.

57. Zhang H, Dang Z, Zheng LC, Yi XY. Remediation of soil cocontaminated with pyrene and cadmium by growing maize (Zea mays L.). Int J Environ Sci Technol. 2009;6(2):249-58.

58. Mahar A, Wang P, Ali A, Awasthi MK, Lahori AH, Wang Q, et al. Challenges and opportunities in the phytoremediation of heavy metals contaminated soils: A review. Ecotoxicol Environ Saf. 2016;126:111-21.

59. Barceló J, Poschenrieder C. Phytoremediation: Principles and perspectives. Contrib Sci. 2003;2(3):333-44.

60. Suko T, Fujikawa T, Miyazaki T. Transport phenomena of volatile solute in soil during bioventing technology. J ASTM Int. 2006;3(7)

61. Lee M, Yang M. Rhizofiltration using sunflower (Helianthus annuus L.) and bean (Phaseolus vulgaris L. var. vulgaris) to 
remediate uranium contaminated groundwater. J Hazard Mater. 2010;173(1-3):589-96.

62. Susarla S, Medina VF, McCutcheon SC. Phytoremediation: An ecological solution to organic chemical contamination. Ecol Eng. 2002;18(5):647-58.

63. Prasad MNV. Sunflower (helinathus annuus L.) - A potential crop for environmental industry. Helia. 2007;30(46):167-74

64. Jing YD, He ZL, Yang XE. Role of soil rhizobacteria in phytoremediation of heavy metal contaminated soils. J Zhejiang Univ Sci B. 2007;8(3):192-207.

65. Badali H, Prenafeta-Boldu FX, Guarro J, Klaassen CH, Meis JF, De Hoog GS. Cladophialophora psammophila, a novel species of Chaetothyriales with a potential use in the bioremediation of volatile aromatic hydrocarbons. Fungal Biol. 2011;115(10):101929.

66. Silva-Castro GA, Rodelas B, Perucha C, Laguna J, González-López J, Calvo C. Bioremediation of diesel-polluted soil using biostimulation as post-treatment after oxidation with Fenton-like reagents: Assays in a pilot plant. Sci Total Environ. 2013;445446:347-55.

67. Parmar P, Dave B, Panchal K, Subramanian RB. Identification of Potential Species Croton bonplandianum, Sedges and Balanitis aegyptiaca for the Application of Phytoremediation. 2013 Jun 4 [cited 2021 Dec 24];2013. Available from: http://www.scirp.org/journal/PaperInformation.aspx?PaperID=335 50

68. Marmiroli N, Marmiroli M, Maestri E. Phytoremediation and phytotechnologies: A review for the present and the future. Soil Water Pollut Monit Prot Remediat. 2006;69:403-16. 